\title{
CONCOMITANT INVOLVEMENT OF THE SHOULDER JOINTS BY PROLIFERATIVE AND DEGENERATIVE ARTHRITIS
}

\author{
BY \\ ROBERT H. RAMSEY \\ From the Departments of Surgery and Surgical Pathology (Dr. Lauren V. Ackerman), \\ Washington University School of Medicine, St. Louis, Missouri
}

This record of an unusual case of arthritis involving both shoulders and both wrists in an elderly female patient emphasizes the difficulty of understanding and classifying the underlying disease process in the chronic arthritides, even when good pathologic material is available for study.

\section{Case Report}

Mrs. M.M. (B.H. 175892), a 75-year-old widow of Yugoslavian birth, entered Barnes Hospital on September 7, 1949, with the history of having insidiously developed intermittent pain and stiffness in both shoulders over a ten-year period. These symptoms gradually progressed and about two years before admission, the patient noticed swelling in both shoulders, and pain, swelling, and stiffness in both wrists. From this time on, the pain was moderately severe, almost constant, and aggravated by motion; and the patient became unable to raise either hand up to her hair. Past history revealed that she had been in good general health and had actively done housework all her life.

Physical Examination.-The patient was an alert, asthenic, elderly female in no acute distress and not appearing ill. There was a marked thoracic scoliosis to the right. There was a huge effusion of the right shoulder presenting anteriorly and laterally and a slight effusion of the left shoulder. There was pronounced atrophy of the muscles around both shoulders and both were subluxated upward although they could be passively moved completely around the margin of the glenoid with a coarse grating sensation. All active and passive motion was painful; there was slight peri-articular tenderness. Both wrists showed a prominent effusion with " ballooning" laterally and medially, and in these joints there was slight limitation of motion with pain and slight tenderness. The elbows, hips, knees, and ankles were normal. Heberden's nodes were present. No subcutaneous nodules were found. Head and neck, heart and lungs, abdomen, and neurological examinations were negative. Pelvic examination revealed a lesion on the right labia majora, 1 in. in diameter, which was diagnosed as epidermoid carcinoma.

Laboratory Findings.-Kahn test negative.

Corrected sedimentation rate: $1.3 \mathrm{~mm} . / \mathrm{min}$. (normal $0 \cdot 1$ $0.4 \mathrm{~mm} . / \mathrm{min}$.).

Haemoglobin: 10. g.

Red blood count: 4 million.

White blood count: 8,500 with normal differential count.

Urine analysis: negative.

Culture of joint fluid revealed no growth; the fluid was of clear amber colour and of normal viscosity. 

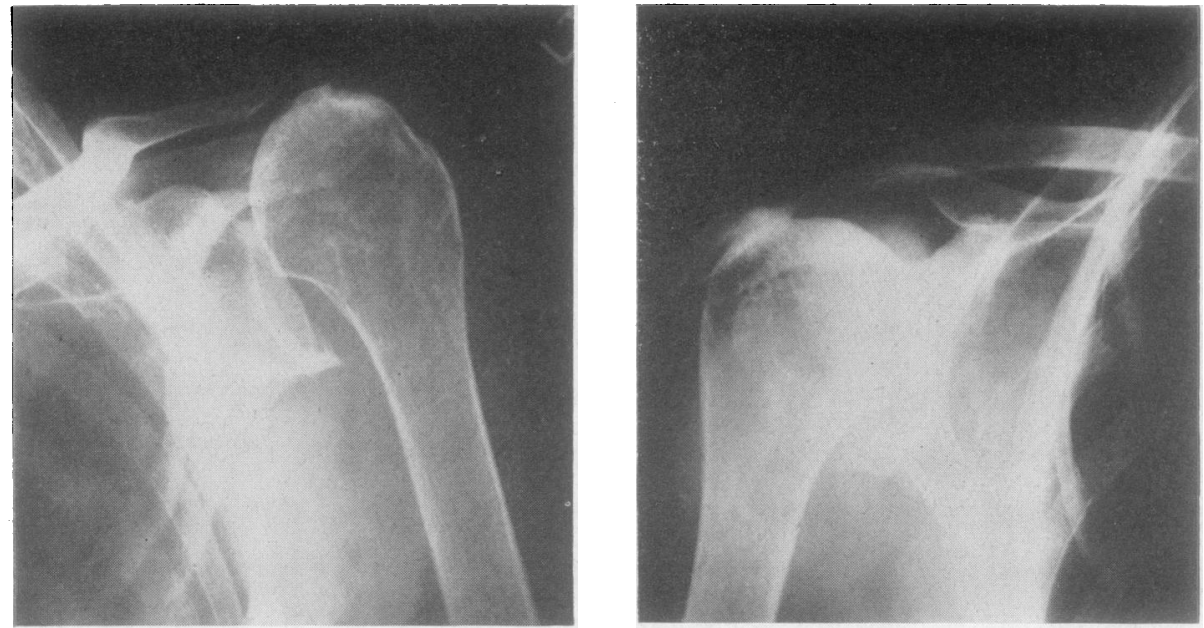

Figs 1 and 2.- $X$, rays of shoulders, showing unusual symmetrical change.

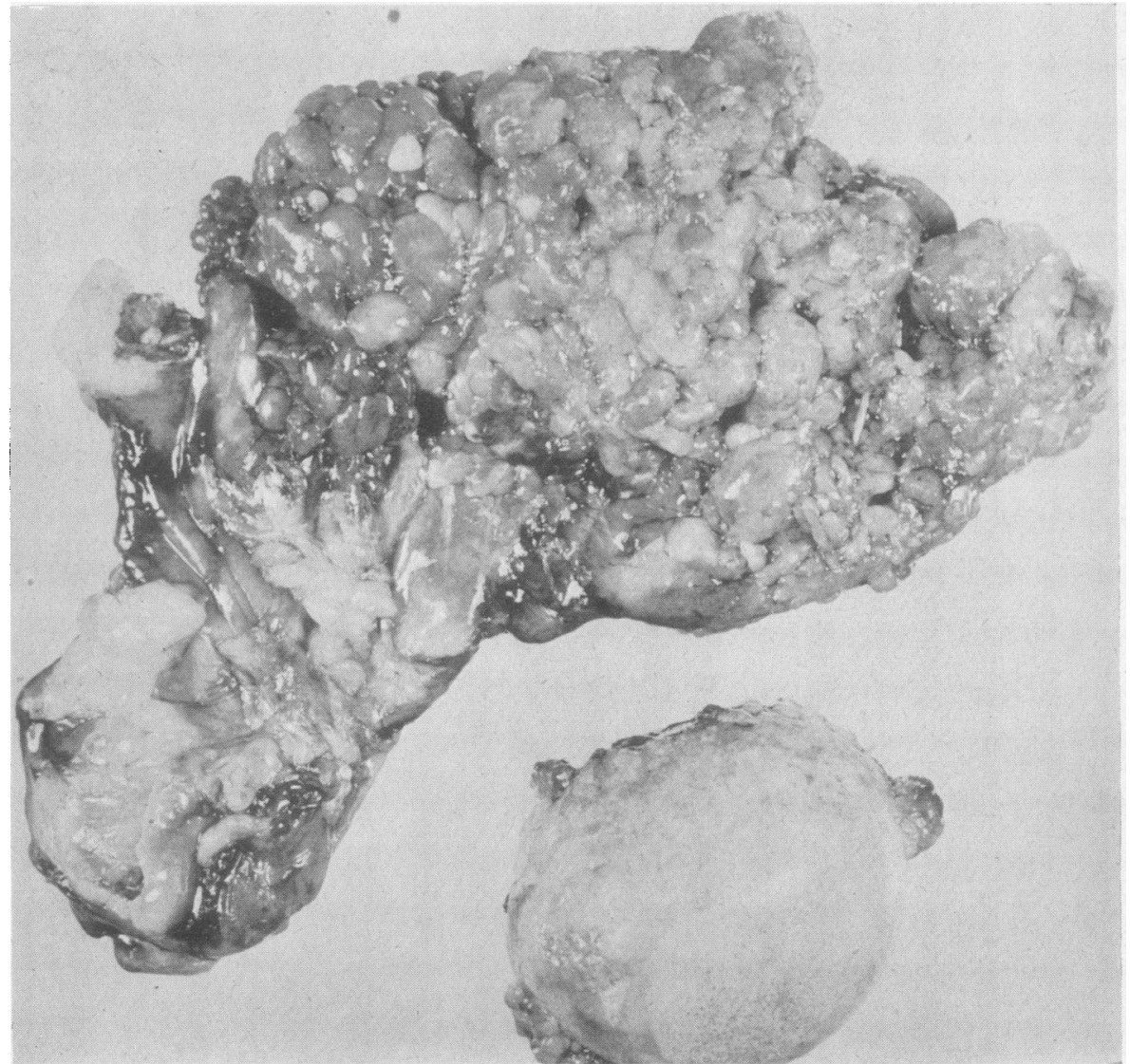

FIG. 3.-Gross appearance of removed synovium and resected humeral head. 
CONCOMITANT PROLIFERATIVE AND DEGENERATIVE ARTHRITIS 139

Radiological Examination.- $X$ rays of the shoulders (Figs 1 and 2) revealed an upward subluxation, decrease in width of joint space, irregular demineralization of the bones of the shoulder girdle, slight marginal spurring of the humeral head and glenoid, and subchondral condensation of the humeral head, the latter being particularly marked on the right side. $X$ rays of the wrists showed soft tissue swelling, irregular demineralization of the distal radius, the ulna, and all of the carpals, and marked narrowing of the radialcarpal articulations.

Operation.-On September 8, 1949, the right shoulder was explored by an anterior approach. When the joint was entered an estimated $250 \mathrm{ml}$. clear amber-coloured synovial fluid escaped. The entire anterior and lateral synovium was removed, and the upper end of the humerus was resected just distal to the articular margin (Figs 3 and 4).

A two-month follow-up revealed no recurrence of the effusion, but only a few degrees of active motion were possible because of the painful grating produced by attempted motion. The wrists and left shoulder were essentially unchanged. The epidermoid carcinoma of the vulva was treated by the Department of Obstetrics and Gynaecology shortly after the operation on the shoulder.

\section{Pathology}

Gross.-The synovial specimen (Fig. 3) measured $18 \times 8 \mathrm{~cm}$. in area and was 1 to $2 \mathrm{~cm}$. thick. The bulk of the tissue was hypertrophied synovium with a layer of loose fibrous tissue 1-2 mm. thick representing part of the underlying capsule. The synovial surface was composed of closely packed nodules and papillary masses of hypertrophied synovium and was of reddish-grey colour. Some of the nodules were as much as $1 \mathrm{~cm}$. in diameter. A few of the villi were yellowish-white and had the consistency of fat. The humeral head (Fig. 4) was seen to be devoid of cartilage

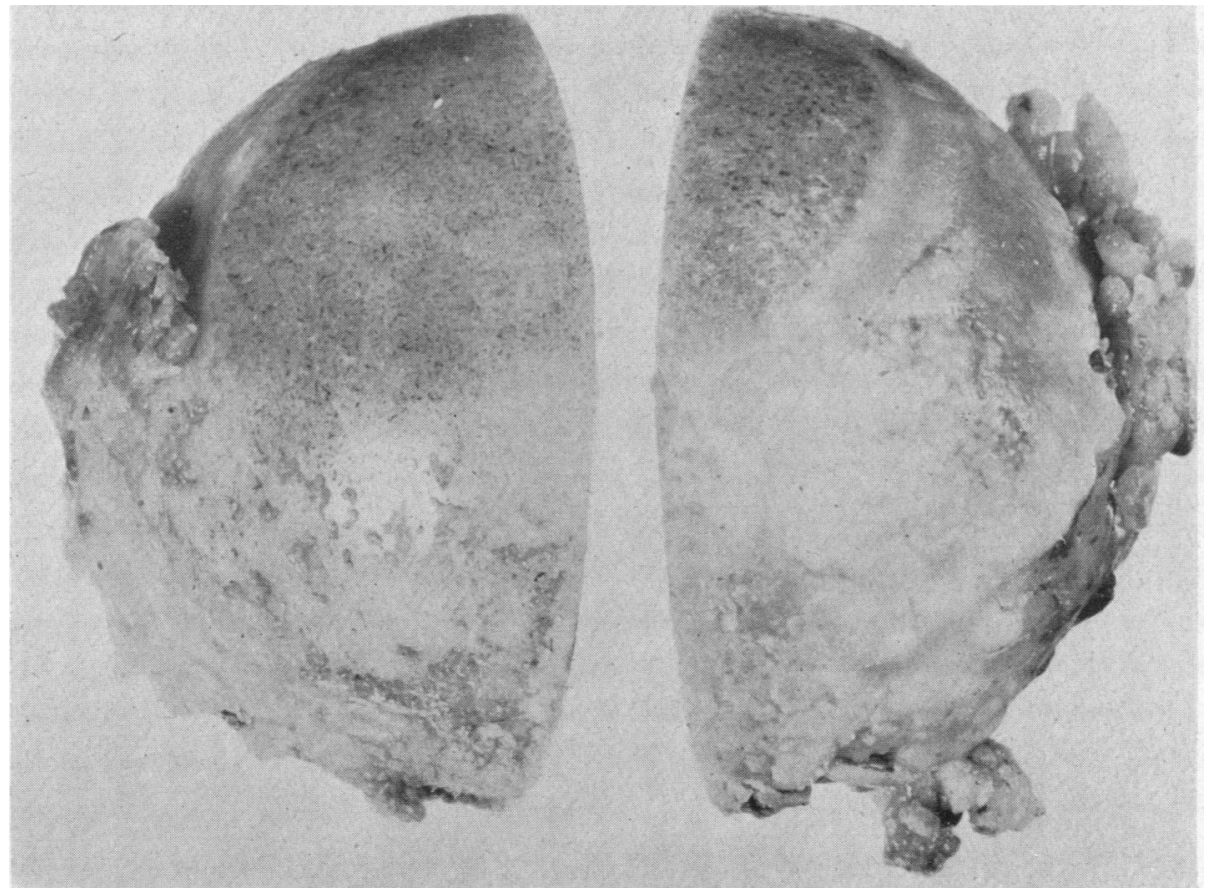

FIG. 4.-Halves of humeral head (enlarged) showing polished, eburnated surface and pitting. 
except near the articular margin, and most of the surface was a highly polished, eburnated bone covered with fine, shallow, punctate pits. Near the articular margin a portion of the articular surface was covered by a thin layer of white, fairly dense, fibrous tissue, and a few irregular overgrowths of a dull hyaline cartilage were present.

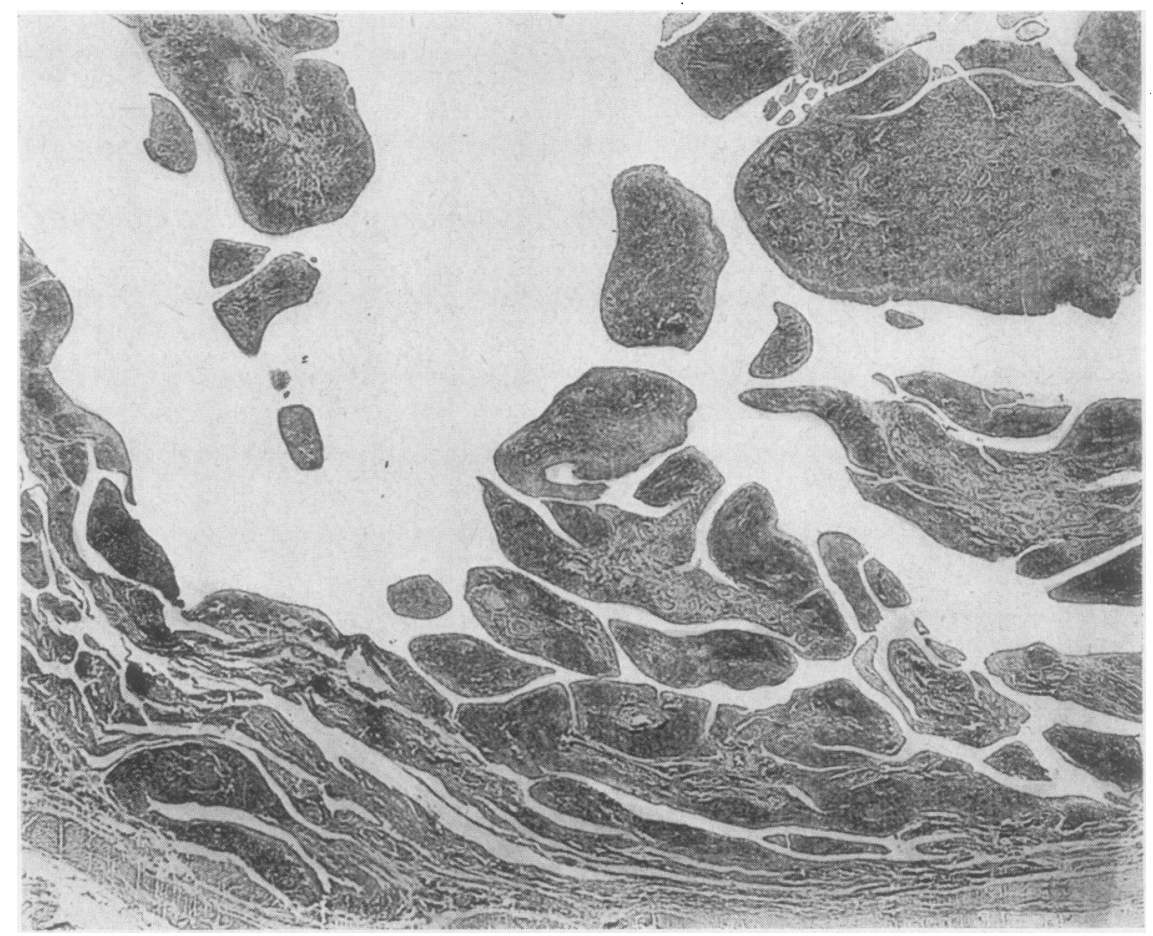

FIG. 5.-Low-power photomicrograph of synovium.

Microscopic.-The synovium (Figs 5 and 6) showed a villous type of hypertrophy; the surface layer was 3 to 5 cells thick, and was made up of cuboidal, ovoid, and flat cells 10-12 microns in diameter. The stroma of these villi was composed of a vascular fibrous connective tissue with a relatively small amount of collagenous intercellular substance, and showed slight oedema. The dominant features were the diffuse plasma-cell infiltration and the multiple focal collections of both plasma cells and lymphocytes. In these collections the plasma cells were usually more numerous than the lymphocytes. A few polymorphonuclear leucocytes were seen.

Section of the humerus (Fig. 7) showed an articulating surface of compact bone which immediately below the surface became trabecular in structure; the deeper trabeculae were thin and somewhat sparse. Many of the lacunae close to the articulating surface were empty. The intertrabecular connective tissue just below the surface was a loose cellular fibrous tissue with moderate plasma-cell and lymphocytic infiltration; deeper it was adult adipose tissue with many small 


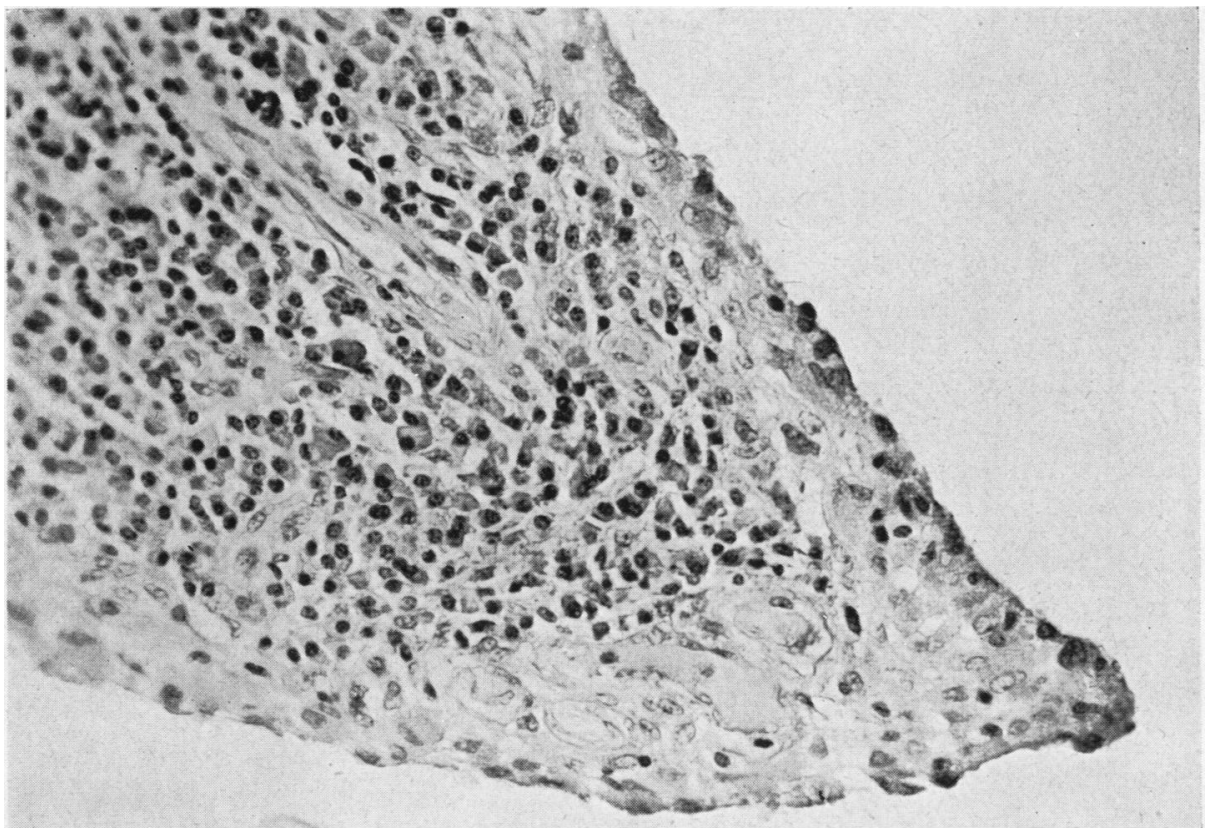

FIG. 6.-Photomicrograph $(\times 400)$ of synovial villus, showing hyperplasia of the.living cells and stroma, and prominent plasma-cell infiltration.

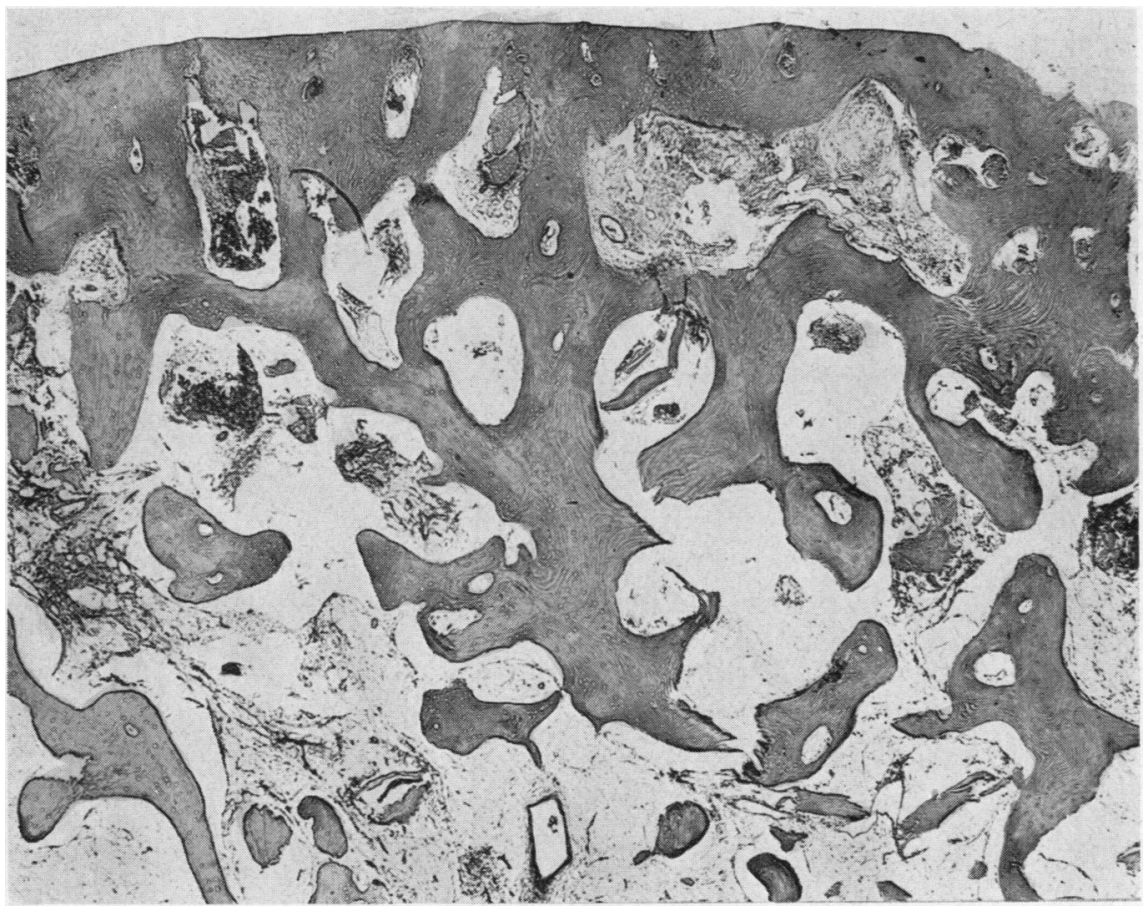

Fig. 7.-Photomicrograph $(\times 225$ of humeral head, showing articulating bony surface at the top. 
fibrous strands and no inflammatory elements. Near the articular margin the surface of the bone was covered with a thin layer of cellular fibrous tissue with the cells and collagen fibres arranged parallel to the surface.

\section{Discussion}

From the pathological standpoint it is immediately apparent that at least part of the change in this shoulder joint represented a severe form of degenerative or osteo-arthritis. The loss of the cartilage surface with the formation of a polished, eburnated bone surface, the marginal lipping, and the subluxation are typical features that have been described by virtually all published studies of this condition. However, as Keefer (1935) points out:

in spite of the fact that pain in the shoulder is extremely common, it is not due to osteo-arthritis very often;

it would therefore be most unusual to see a severely symptomatic degenerative arthritis involving both shoulders and both wrists in a patient without any symptomatic joint disease in the weight-bearing joints unless there was some concomitant disease process in these symptom-producing joints.

In addition, this case shows evidence of rheumatoid arthritis in the pronounced synovial proliferation with round-cell infiltration, as well as in the mild connectivetissue proliferation with inflammatory changes in the marrow spaces just below the articular surface. If it is true, as claimed by Allison and Ghormley (1930) and by Rosenberg (1949), that the non-perivascular collections of round cells to form follicles are pathognomonic of rheumatoid arthritis, then this case must fall into that category. It is the author's feeling, however, that these follicle-like collections are non-specific. The distribution of joint disease in this case is also suggestive of rheumatoid arthritis.

Nichols and Richardson (1909), in their comprehensive study of the pathology of what they termed "proliferative" and "degenerative" arthritis, describe a marked proliferation of the synovium that sometimes occurs in the latter type and may result in the formation of papillary masses; this they termed "fungoid joint ". However, they were grouping under the term " degenerative arthritis" such conditions as Charcot's joints, traumatic arthritis, osteochondromatosis, and gout. As later studies appeared and degenerative arthritis became more exactly defined the synovial change became a less prominent feature. Thus, Ely (1914) notes focal round-cell infiltration but no real proliferation of the synovium; Allison and Ghormley (1930) state that the portion of the synovium near the articular margin may become villous, show hyperplasia, and have occasional areas of smallcell infiltration; and Abrams (1949) mentions only that " the synovial membrane frequently is normal but may show an increase in number and size of villi ". So it seems that judged by the more recent concepts of the pathology of arthritis the synovial proliferation in this case cannot be considered to be the result of degenerative arthritis alone.

This case was reviewed by Dr. Granville Bennett (1950), who considered it 
to represent the simultaneous occurrence of rheumatoid and degenerative arthritis in the same joints. Dr. J. Albert Key (1950) did not think the proliferative component of this case could be classified as rheumatoid arthritis. Our search of the literature revealed no similar change of such a severe nature in the shoulder joint.

\section{Summary}

An unusual case of severe chronic arthritis involving both shoulders and wrists in a 75-year-old female is reported, with a pathological study of the surgically removed synovial membrane and humeral head. The clinical, radiographical, and pathological findings lead to the conclusion that this condition may represent the concomitant occurrence of proliferative and degenerative arthritis.

\section{REFERENCES}

Abrams, N. R. (1949). In “Comroe's Arthritis”, ed. J. L. Hollander, 4th ed., p. 527. Lea and Febiger, Philadelphia.

Allison, N., and Ghormley, R. K. (1930). “Diagnosis in Joint Disease ”, pp. 138 and 178. Wood, New York.

Bennett, G. A. Personal communication.

Ely, L. W. (1914). "Diseases of Bones and Joints", p. 136. Surgery Publishing Co., New York.

Keefer, C. S. (1935). Med. Clin. N. Amer., 18, 947.

Key, J. A. (1950). Personal communication.

Nichols, E. H., and Richardson, F. L. (1909). J. med. Res., 21, 149.

Rosenberg, E. F. (1949). In "Comroe's Arthritis", ed. J. L. Hollander, 4th ed., p. 128. Lea and Febiger, Philadelphia.

\section{Atteinte Concomitante des Articulations de l’Épaule par l'Arthrite Proliférative et Dégénérative \\ Résumé}

On rapporte un cas rare d'arthrite chronique grave atteignant les articulations de l'épaule et du poignet chez une femme de 75 ans. L'examen anatomo-pathologique des membranes synoviales prélevées chirurgicalement et l'étude clinique et radiologique de la malade mènent à la conclusion qu'il pourrait s'agir d'une arthrite proliférative et dégénérative survenant en même temps.

\section{Implicación Concomitante de las Articulaciones del Hombro por Artritis Proliferativa y Degenerativa}

\section{RESUMEN}

Se relata un caso raro de artritis crónica grave afectando las articulaciones del hombro y de la muñeca en una mujer de 75 años. La investigación anatomo-patológica de las membranas sinoviales extraidas quirúrgicamente y el estudio clínico y radiográfico de la enferma llevan a la conclusión de que se pueda tratar de una artritis proliferativa y degenerativa concomitante. 